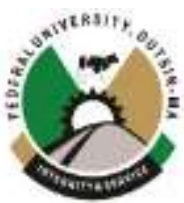

\title{
ASSESSMENT OF URBAN GENERATED CLIMATE ANOMALY IN OKENE TOWN, OKENE LOCAL GOVERNMENT AREA OF KOGI STATE, NIGERIA
}

Ishaya, $\mathbf{S}$.

Department of Geography and Environmental Management, University of Abuja

E-mail: ishayasunny@yahoo.com \& ishaya.Sunday@uniabuja.edu.ng Tel: 08029742624

\begin{abstract}
This study assessed urban generate climate change in Okene town of Kogi State, Nigeria. The objectives of this study include acquiring temperature, relative humidity and solar radiation data from SWAT satellite image from 1986 to 2016; determine the trend, normality, changes in temperature, relative humidity and solar radiation in the study area from 1986 to 2016. Climate data was collected from the Soil and Water Assessment Tools (SWAT) from 1986 to 2016 of Okene Town. Simple Statistical Measures of mean, maximum, minimum, standard deviation, Average deviation, coefficient of variation, skewness and kurtosis were used for discerning the trends and normality of temperature, relative humidity and solar radiation. The chi square statistical test was use to test the study hypothesis. The trend line equation shows positive for temperature $(0.0567 x+26.27)$, Solar radiation $(0.036 \mathrm{x}+18.1)$ and negative trend in relative humidity $(\mathrm{y}=-0.001 \mathrm{x}+0.733)$. Chi square statistical result shows that there are significant changes in temperature, relative humidity and solar radiation over the past three decades in Okene town of Kogi State. In tackling this anomaly, there is need for greening the town by embanking on radical planting of trees and creation of cool pavement technologies towards cooler surfaces by convection or higher reflectance as adaptive/mitigation measures against Urban Heat Island in Okene town.
\end{abstract}

Keywords: SWAT, Urban, Generate, Climate Change, Okene Town, Kogi State.

\section{INTRODUCTION}

Climate change has emerged as one of the defining issues of the early 21 st century and this has become laudable with the declaration of the United Nation Sustainable Development Goals (SDGs). The central aim of the set of 17 goals imagines a future fifteen years are to get rid of poverty and hunger, and safe from the worst effects of climate change United Nations (2015). It was acknowledged that achieving the ambitious 17 SDGs is bleak in the face of climate change. In fast growing urban areas to end poverty in all its forms (Goal 1); end hunger, achieve food security and improved nutrition and promote sustainable agriculture (Goal 2); ensure healthy lives and promote wellbeing for all at all ages (Goal 3); ensure availability and sustainable management of water and sanitation for all (Goal 6); promote sustained, inclusive and sustainable economic growth, full and productive employment and decent work for all (Goal 8); build resilient infrastructure, promote inclusive and sustainable industrialization and foster innovation (Goal 9); make cities and human settlements inclusive, safe, resilient and sustainable (Goal 11), take urgent action to combat climate change and its impacts (Goal 13); protect, restore and promote sustainable use of terrestrial ecosystems, sustainably manage forests, combat desertification and halt and reverse land degradation and halt biodiversity loss (Goal 15) is very bleak in changing climatic conditions.

Global surface temperatures in the past three decades are $0.88^{\circ} \mathrm{C}$ higher than the start of the 20th century, with two thirds of this warming having occurred since 1975 (Adinna, Enete and Arch, 2009). Recent researches confirm that the imprint of human induced climate change can be recognized in current events (Adakayi and Ishaya). It is perceived that the rapid urban growth would initiate improvement of both living condition and the quality of the environment, but it is well understood that the conversion of agricultural, vegetation and wetland in urban areas to build up areas and the attending population growth usually comes with a vast increase in surface temperature (Ifatimehin, Ujoh and Magaji, 2009). Globally, human induced changes on the environment and its attendant impacts are mostly associated with the accelerated economics growth in an urbanizing environment (Ifatimehin, Ishaya and Fanan, 2010). In relation to these, the urban heat island effect (UHIE) has been the subject of numerous studies in recent decades, because it is associated with temperature of the central urban location rising with several degrees higher than its suburbs and the rural areas. Urbanization is the major driving force altering local and regional environment. The simultaneous rapid growth in both population and the consequent changes in land use patter globally characterize this heat island development (Camilo, 2010) and thisculminate in temperature rise. Differences in temperature in urban centre force the development of alien metrological events to the area such as increased precipitation, which pose threat to the environment and human population (Zhao and Wang, 2002).

In developing countries like Nigeria, this uncontrolled population and areal expansion have become an issue changing environment scientist impression because of the escalating problem of urban congestion, poor housing crowded transportation, lack of basic services, ill health (mostly due to 
increase in temperature), epidemics etc. It is noted that the most significant characteristic of man's induced changes in the urban environment are the variation in thermal properties of the built up land surface, soil and impervious surface which result in removal of shrubs and trees which serve as a natural cooling effects of shading and evapotranspiration and contributes to the reduction in outgoing long wave radiation by hindering the loss of sensible heat and distribution of heat (Peter and Ovuyovwiroye, 2010) and Bulkeley, 2010).

The urban heat island has been the subject of numerous studies in recent decades, because it is associated with the temperature of the central urban location rising with several degrees higher than those of nearby rural areas of elevation (Ifatimehin and Adeyemi, 2008). It is claimed that global warming is an artifact of urban heat island effect and is simply an artifact of urban myth effect (Stewart and Oke, 2009). Locally in Okene town, it is noted that as population centre grow they tend to modify a greater area of land and have a corresponding increase in average temperature. The land use pattern in Okene has change gradually from vegetated, agricultural to commercial and residential area and that has lots of implication in the study area as vegetation's that serve as carbon sinks are been replaced with asphalts and buildings in order to meet the need of its inhabitants and so in return changing environmental conditions.

Many researchers have worked on climate change in Nigeria, effect of urban heat island, temperature variation in urban centre but none of these studies worked on urban generate climate change. Adakayi and Ishaya (2015) assessed annual minimum temperature in some parts of Northern Nigeria; Ifatimehin and Adeyemi (2008) assesed urban heat island of Lokoja town and estimated the surface temperature of the town; Ifatimehin, Ishaya and Fanan (2010) analyzed temperature characteristics in Lokoja town using informatics technique. It is obvious that several studies assessed possibilities of urban heat island in Kogi State but study on urban generate climate change are lacking particularly in Okene town of Okene Local Government Area of Kogi State and this study was set out towards closing this existing gap in literature.

\section{STUDY AREA}

The SWAT weather elements data collection point in Okene town is located at latitude $7^{0} 33^{1} 00^{11}$ and longitude $6^{0} 14^{1} 0^{11}$. In term of relative location, the town shares bounder with Adavi
Local Government Area to the North, West by Ijumu Local Government Area, and East by Ajaokuta Local Government Area and to the South by Ogori Mangogo Local Government Area and Edo State. Okene town is surrounded by various hills, steepy in some area and plain in other areas. Some areas lie on the gentle slope with height of about 500 feet to 800 feet above sea level, while others lies on a steep slope with height of above 1000 feet 1500 feet about sea level (Figure 1). Okene is characterized by igneous and metamorphic rock of the basement complex (Ododo, 2001).

The tropical climatic characteristics is pronounced in the study area thus the climate is governed by the climatological process that drives and controls the tropical wet and dry climate using Koppen classification system. The wet season spreads over a minimum of six (6) months and it extends from May to October and to November to January we have harmattan of cool dry air and dust in nature. This implies that the dry season five months i.e. from November to April (Ododo, 2001).

The study area is within the guinea savanna vegetation region of Nigeria. The trees are scattered and deciduous; they shed leaves during dry seasons while the grasses found here range from 1.6 to 2 meters in height. The dominant economic trees are cashew, mango, mahogany, locus beans and palm trees. Generally, the vegetation consists essentially of short to tall trees of various sizes and height with shrubs, low forest and over the years, the vegetation suffers from seasonal bush burning, farming and indiscriminate lumbering. Lateritic soils dominate the area looking dark brown to reddish yellow due to sesqui-oxide on the surface. This soil is highly leached and contained iron and supports growth of tuber crops like yams, cassava and cocoa yam, due to accumulation of nutrient at the B horizon

The 2006 population census exercise puts the population of Okene at 320, 260 with a projected population of 452,000 in 2019 according the United Nations (2019). The predominant inhabitants of Okene town are of the Ebira tribe of central Nigeria and they are predominantly Muslims and Christians and few others practice African Tradition religion. Most women are into cloth weaving, trading, tailoring, salon operation and knitting of clothes; while most men are into farming, trading vocational works like carpentry, auto-mechanic, building, welding while a few others are into white collar jobs (Ododo, 2001). 


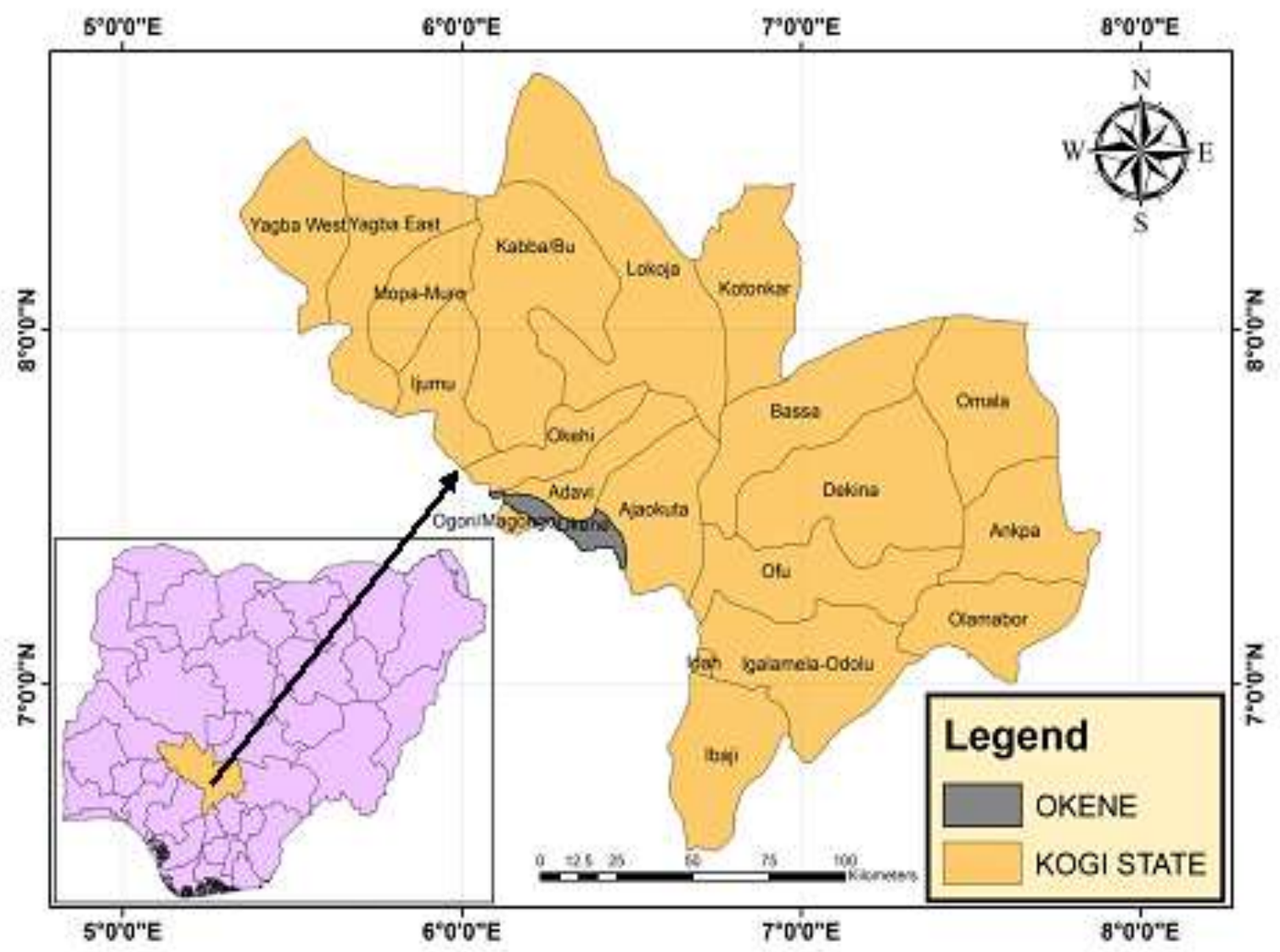

Figure 1: Map of Kogi State showing Okene LGA.

Source: GIS Lab, Department of Geography and Planning, KSU, Anyigba (2019).

\section{METHODS}

The temperature, relative humidity and solar radiation data that were used in this research were downloaded from the (SWAT site) Soil and water Assessment Tools for the year 1986 to 2016 from SWAT site (http://www.sawt.com). The temperature, relative humidity and solar radiation data that were downloaded from the SWAT site were subjected to both descriptive and nonparametric test. Time series graph, Standard measures of minimum, maximum, range, arithmetic mean, average deviation standard deviation, Coefficient of Variation Skewness and Kurtosis were used to analyzed the data obtained from the SWAT site.

Chi square is a statistical test was used to measure how expectations compare to actual observed temperature, relative humidity and solar radiation data. The chi-square was adopted in testing the hypothesis, which made it possible for the researcher to either reject or accept the hypothesis used to establish whether there are significant changes in temperature, relative humidity and solar radiation in the study area over the past three (3) decades.

\section{RESULT AND DISCUSSION}

Surface Temperature Trend in Okene town from 1986-2016 Findings depict that from the year 1986 to 2016, minimum temperature is $25.98^{\circ} \mathrm{C}$, maximum temperature is $28.50^{\circ} \mathrm{C}$, the average deviation is $0.63^{\circ} \mathrm{C}$ and the standard deviation is $0.73^{\circ} \mathrm{C}$. The standardized coefficient of kurtosis $\left(\mathrm{Z}_{2}\right)$ from the year 1986 to 2016 depicts abnormality at $95 \%$ significant level, hence showing a significant deviation from the normal. Mean temperature in the study area is $27.18^{\circ} \mathrm{C}$ with the highest annual temperature $\left(28.59^{\circ} \mathrm{C}\right)$ recorded in the year 2011 , while the lowest yearly mean temperature $\left(25.98^{\circ} \mathrm{C}\right)$ was recorded in the 1998. Figure 2 portrays a significant increase from the year 1986 to 2016. The drop in temperature from the year 2012 to 2016 can be attributed to the recent flooding experienced in the state increasing soil moisture and influence the temperature of the area. Temperature trend line equation in Okene town yielded a positive straight line equation of $\mathrm{y}=0.0567 \mathrm{x}+26.27$ and a coefficient of determination $\mathrm{R}^{2}=0.4979$. It is obvious that temperature in the study area has been in an increase. The findings of this study affirm that observed by Hassan and Ishaya (2010); Ishaya and Hassan (2013); Adakayi and Ishaya (2016) in their assessment of annual temperature in some parts of Northern Nigeria, which they found out that temperature in recent been increasing steadily. This is likely due to increase in 
urbanization and anthropogenic activities as a result of

population increase in Okene town.

Table 1: Surface Temperature Descriptive Statistical Result of Okene Town

\begin{tabular}{|l|l|}
\hline Statistics & Statistical Results \\
\hline Minimum Temperature & 25.97667213 \\
\hline Maximum Temperature & 28.59660274 \\
\hline Mean $(\mathrm{X})$ & 27.28664 \\
\hline Average deviation(AD) & 0.626206559 \\
\hline Standard deviation(SD) & 0.731186976 \\
\hline Coefficient of variation $(\mathrm{CV})$ & 0.0269 \\
\hline Skew $\left(\mathrm{Z}_{1}\right)$ & 0.26 \\
\hline Kurtosis $\left(\mathrm{Z}_{2}\right)$ & -0.987 \\
\hline
\end{tabular}

Source: Researcher Analysis, 2019.

\section{Relative Humidity Trend in Okene town from 1986-2016}

The minimum relative humidity observed is $0.65 \%$, maximum relative humidity is $0.75 \%$, the average deviation is $7.50 \%$ and the standard deviation is $11.58 \%$. The standardized coefficient of skweness (2.641) kurtosis (6.982) from the year 1986 to 2016 depicts abnormality at $95 \%$ significant level, hence showing a significant deviation from the normal (See table 2). The mean relative humidity in the study area is $0.70 \%$. Generally relative humidity shows downward trend from 1986-2016. The decline in relative humidity can be due to increase trend temperature and solar radiation in the area. The years between 2002-2007 depicts anomaly drop in relative humidity but gradually rose in the year 2002 (See Figure 3). The trend line equation of relative humidity in Okene town yielded a negative straight line equation of $y=-0.001 x+0.733$ and a coefficient of determination $R^{2}=0.308$. It is obvious that relative humidity in the study area has been declining. This is likely due to increase in urbanization and anthropogenic activities as a result of population increase and conversion of vegetal and agricultural land into urbanized area. The findings of this study concur with the observations of Adinna, Enete and Arch (2009) in their assessment of temperature, rainfall and relative humidity in the oil palm region in Nigeria, which they observed decline in mean relative humidity. This is equally in agreement and with results of Adebayo and Zemba (2003); Aniello et al., (2005); Hunt and Watkiss (2007); Hassan and Ishaya (2010).

Table 2: Relative Humidity Descriptive Statistical Result of Okene Town

\begin{tabular}{|l|l|}
\hline Statistics & Statistical Results \\
\hline Minimum Relative Humidity & 0.652162224 \\
\hline Maximum Relative Humidity & 0.749719468 \\
\hline Mean $(\mathrm{X})$ & 0.700941 \\
\hline Average deviation(AD) & 7.4995535464372 \\
\hline Standard deviation(SD) & 11.57908318938 \\
\hline Coefficient of variation $(\mathrm{CV})$ & 2.4369 \\
\hline Skew $\left(\mathrm{Z}_{1}\right)$ & 2.641 \\
\hline Kurtosis $\left(\mathrm{Z}_{2}\right)$ & 6.982 \\
\hline
\end{tabular}

Source: Researcher Analysis, 2019. 


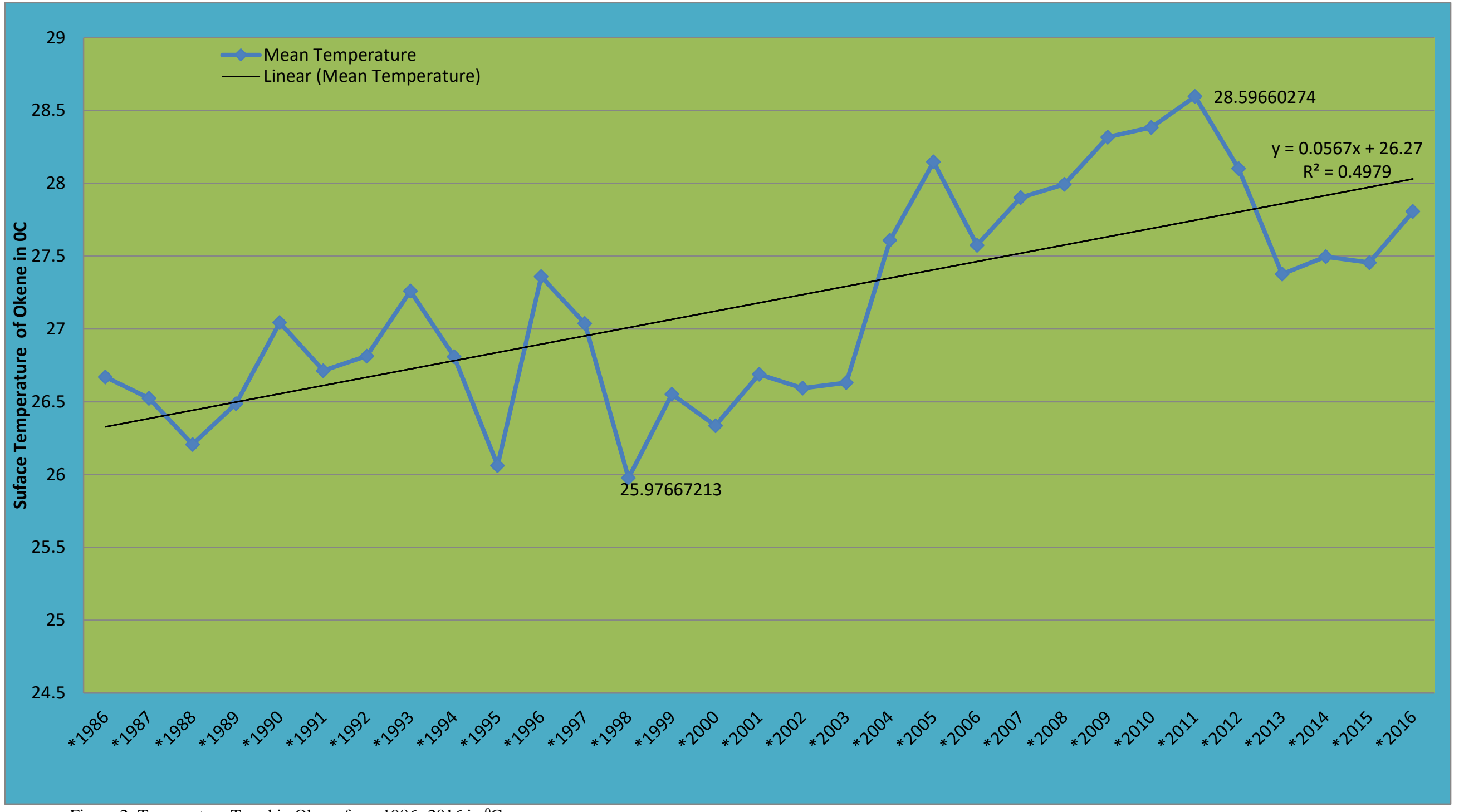

Figure 2: Temperature Trend in Okene from 1986 -2016 in ${ }^{0} \mathrm{C}$

Source: Researcher Analysis, 2019. 
0.748696132

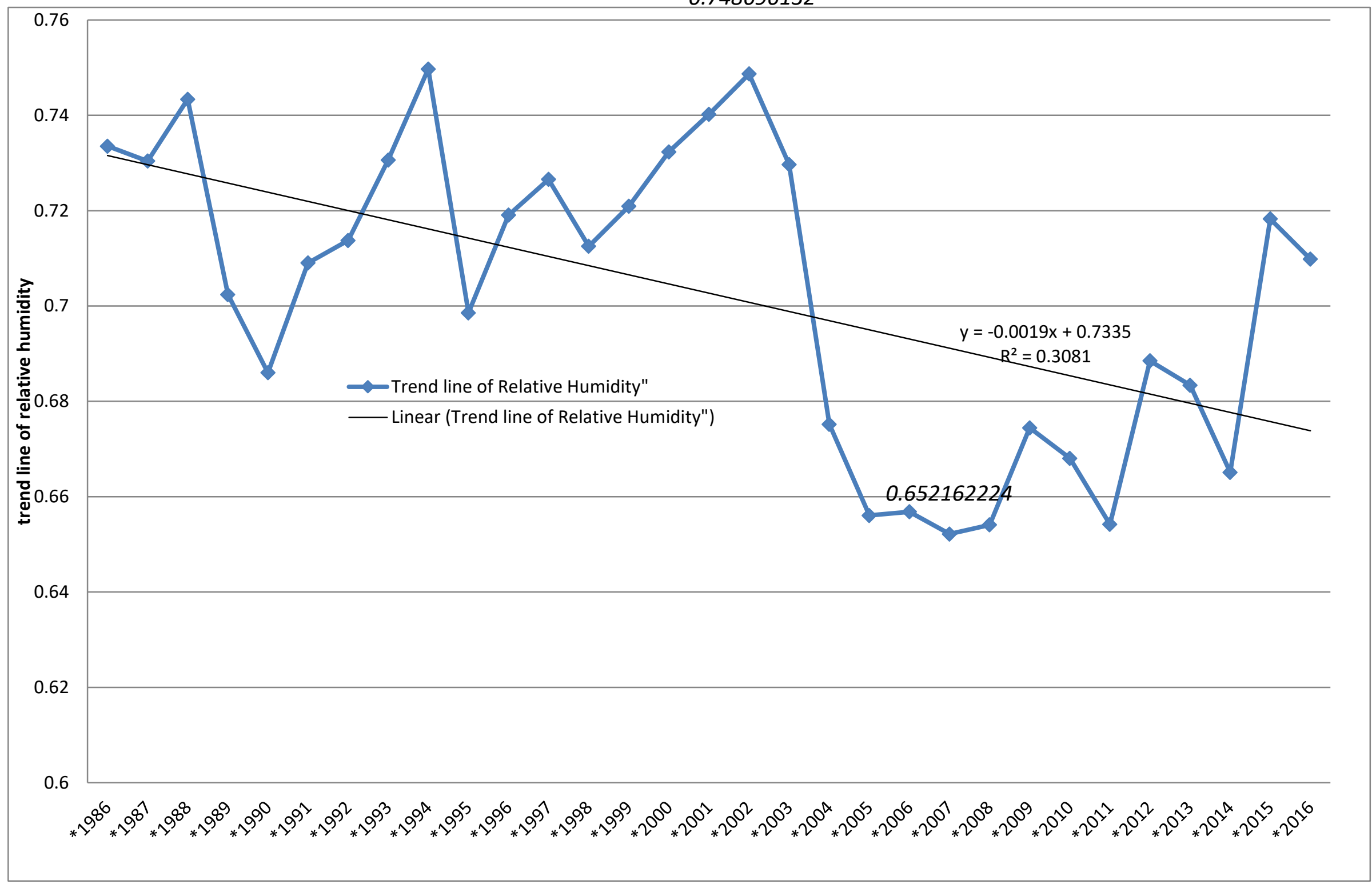

Figure 3: Relative Humidity Trend in Okene from 1986 -2016 in \%

Source: Researcher Analysis, 2019. 
Solar Radiation Trend in Okene town from 1986-2016

From the year 1986 to 2016 the minimum solar radiation is $17.46^{\circ} \mathrm{C}$, maximum solar radiation is $20^{\circ} \mathrm{C}$, the average deviation is 0.45 and the standard deviation is $0.59^{\circ} \mathrm{C}$ and that of standardized coefficient of skewness $\left(\mathrm{Z}_{1}\right)$ and kurtosis $\left(\mathrm{Z}_{2}\right)$ in Okene town in Okene Local Government Area of Kogi State, shows that the yearly average solar radiation readings from 1986 to 2016, were accepted as indicative of abnormality at the $95 \%$ significant level. The mean of solar radiation in the study area is $18.70^{\circ} \mathrm{C}$ with the highest annual solar radiation recorded in the year 2000 and stood at $20.00^{\circ} \mathrm{C}$ while the lowest yearly mean solar radiation was recorded in the 1994 and stood at $17.46^{\circ} \mathrm{C}$. Figure 3 depicts a significant increase in solar radiation from the year 1986 to 2016. The year between 1994-2000, depicts drop in solar radiation but gradually increased in the year 2005 and significant rise in solar radiation was recorded the year 2006 with $20^{\circ} \mathrm{C}$ and solar radiation continually drop till 2015 and rose in 2016 . The drop in solar radiation from the year 2012 to 2016 gave rise to the drop in temperature within the same period. The trend line equation of solar radiation in Okene town yielded a positive straight line equation of $y=0.036 x+18.11$ and a coefficient of determination $R^{2}=$ 0.322. It is obvious that solar radiation in Okene Town has been in an increase. The findings of this study concur with the observation by Yang, X. (2013), statistical analysis of solar radiation, which found out that normality does exists in solar radiation in recent years and affirm the opinion of Peter and Ovuyovwiroye (2010) general overview of climate change in Nigeria.

Table 3: Solar Radiation Descriptive Statistical Result of Okene Town

\begin{tabular}{|l|l|}
\hline Statistics & Statistical Results \\
\hline Minimum Solar Radiation & 17.46045 \\
\hline Maximum Solar Radiation & 20.00227 \\
\hline Mean $(\mathrm{X})$ & 18.69758 \\
\hline Average deviation(AD) & 0.454334 \\
\hline Standard deviation(SD) & 0.585329 \\
\hline Coefficient of variation $(\mathrm{CV})$ & 0.03131 \\
\hline Skew $\left(\mathrm{Z}_{1}\right)$ & -0.259 \\
\hline Kurtosis $\left(\mathrm{Z}_{2}\right)$ & 0.13 \\
\hline
\end{tabular}

Source: Researcher Analysis, 2019.

\section{Validation of Hypothesis and Decision Rule}

This study hypothesized that there are no significant changes in temperature, relative humidity and solar radiation in the Okene town over the study period due to urbanization. The $\mathrm{p}$ value from chi square table for temperature, relative humidity and solar radiation all stood at $(0.003)$ is less than the Alpha significant value of 0.05 , which means that we reject the null hypothesis $\left(\mathrm{H}_{0}\right)$ which states that there are no significant changes in temperature, relative humidity and solar radiation in the study area over the past three decades. Several researches such as Adebayo and Zemba (2003); Hassan and Ishaya (2010); Peter and Ovuyovwiroye (2010); Hassan and Ishaya (2010); Ishaya and Hassan (2013); Aneni and Aisagbonhi (2015); Adakayi and Ishaya (2016) in their diverse assessment of temperature, solar radiation affirm rise in temperature but significant decrease in relative humidity over recent years in Nigeria.

Table 4: Chi Square Test for Temperature, Relative Humidity and Solar Radiation over a period of thirty years.

\begin{tabular}{|l|l|l|l|}
\hline & Temperature & Relative humidity & Solar radiation \\
\hline Chi-Square & 1.000 & 1.000 & 1.000 \\
Df & 30 & 30 & 30 \\
Asymp. Sig. & 0.003 & 0.003 & 0.003 \\
\hline
\end{tabular}

Source: Researchers analysis, 2019. 


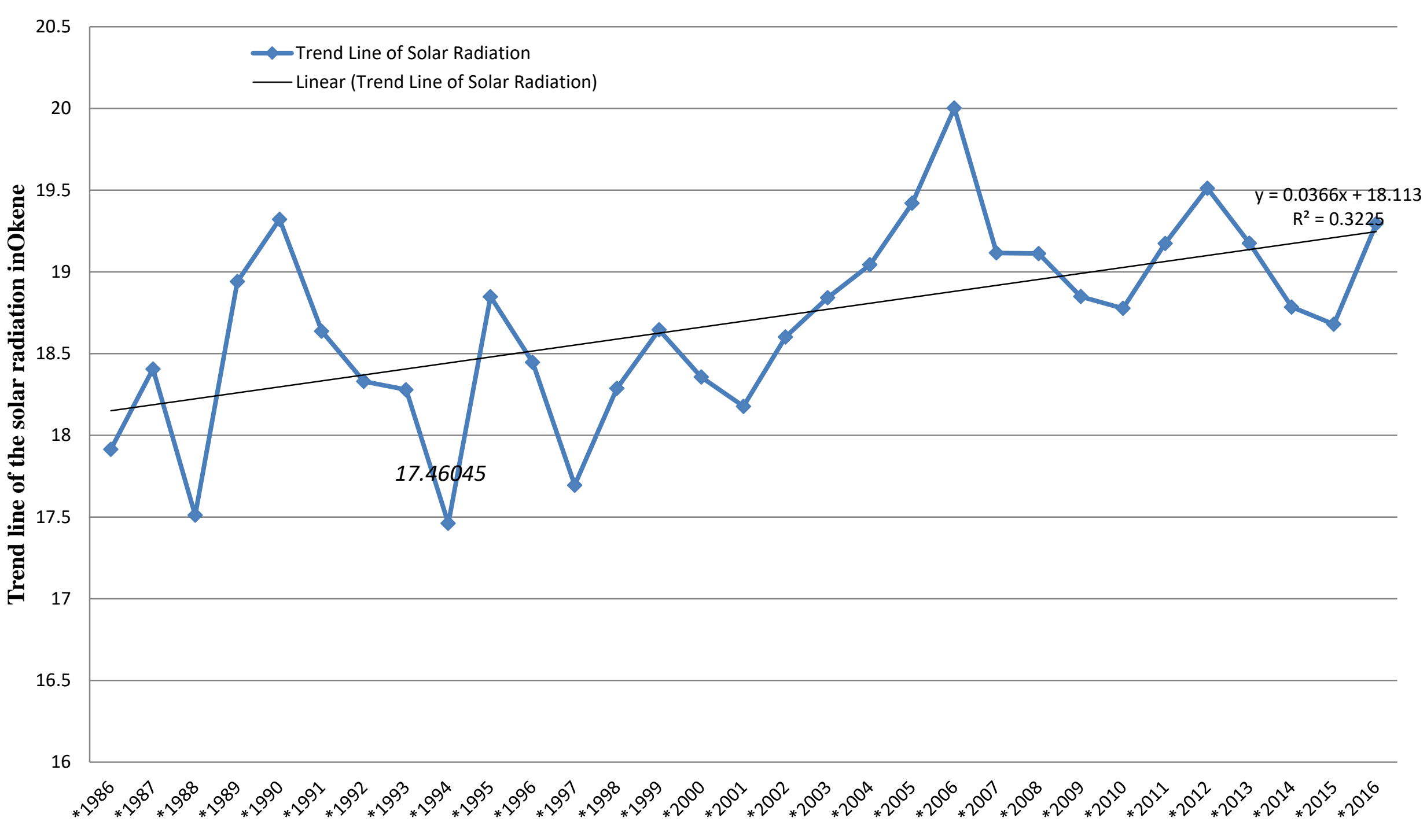

Figure 4: Solar Radiation Trend in Okene from $1986-2016$ in ${ }^{\circ} \mathrm{C}$ Source: Researcher Analysis, 2019. 


\section{CONCLUSION}

This study assessed urban generate climate change in Okene town, Okene Local Government Area of Kogi State using temperature, relative humidity, and solar radiation data obtained from SWAT. This study reveals a significant development of urban generates climate change in Okene town of Kogi State. The rate of urban climate changes also increases as observed by the positive trend line equations of temperature $(0.0567 \mathrm{x}$ $+26.27)$ and Solar radiation $(0.036 x+18.1)$. While significant decrease in relative humidity $(\mathrm{y}=-0.001 \mathrm{x}+0.733)$ was observed. This study conclude that the modifications of land surface as a result of anthropogenic activities of man such as urban development with materials that effectively retains heat, waste heat generated by energy usage in the study area amongst others as significantly increase temperature and solar radiation while in the other hand relative humidity has significantly decrease over the study period in Okene town.

In accordance with the research findings it was recommended that urban planners and developers in Okene town should implement laws that will enhance planting of trees towards regulating and reducing urban generated heat in the study area. There is equally need for sustainable wastes management, reduce pavement development, use of high density green cover, reflective roofing materials, and cool pavement technologies that create cooler surfaces through convection or higher reflectance as adaptive/mitigation measures against UHI in Okene town.

\section{REFERENCES}

Adakayi, P.E., Ishaya, S., (2016). Annual Trend of Mean Temperature in some Part of Northern Nigeria. Ethiopian Journal of Environmental Studies and Management, 9(2), 220227.

Adebayo, A. A., \& Zemba, A. A., (2003). Analysis of micro climatic variations in Jimeta Yola, Nigeria. Global Journal of Social Sciences, 2(1), I9 - 88.

Adinna, E. N., Enete, I. C., \& Arch. T. O., (2009). Assessment of Urban Heat Island and possible adaptations in Enugu Urban using Landsat-ETM. Journal of Geography and Regional Planning, 2(2), 030-036.

Aniello, C., Morgan, K., Bushey, A., \& Newland L., (2005) Mapping Micro urban heat island using 613. Retrieved from http://www.urbanheatislands.com/bibliography.

Ayoade, J.O. (2003). Climate Change: A Synthesis of its Nature, causes, Effects and Management. Ibadan, Nigeria: Vantage publisher.

Bonan, G.B., (2002). Ecological Climatology. Cambridge University Press, Cambridge.

Bulkeley, H. (2010). Cities and the governing of climate change. Annual Review of Environment and Resources, 35(1), 229-253, http://dx.doi.org/10.1146/annurev-environ-072809-101747.
Camilo P.A., (2010), Urban Heat Island (UHI) Effects. Retrieved from http://www.urbanheatislands.com/ on 2011-0908 .

Christensen, O. B., Goodess, C. M., Harris, I., \& Watkiss, P. (2011). European and global climate change projections: Discussion of climate change model outputs, scenarios and uncertainty in the EC RTD ClimateCost Project. In P. Watkiss (Ed.), The Climate Cost project. Final report. Vol. 1: Europe, Stockholm: Stockholm Environment Institute.

Hassan, S.M., and Ishaya S. (2010). Vulnerability of Federal capital Territory of Nigeria (Abuja) to Climate Change. Confluence Journal of Environmental Studies, 5, 10-19.

Hunt, A and Watkiss, P. (2007). Literature Review on Climate Change Impacts on Urban City Centers; Initial findings. ENV/EPOC/GSP (2007) 10. Paris, France: OECD.

Ifatimehin, O. O., Ujoh, F. \& Magaji, J. Y. (2009). An Evaluation of the Effect of Land Use/Cover Change on the Surface Temperature of Lokoja Town, Nigeria. African Journal of Environmental Science and Technology 3(3), 86-90.

Ifatimehin, O. O., \& Adeyemi, J.O. (2008). An assesment of urban heat island of Lokoja town and estimating the surface temperature of a rapidly developing areas. Confluence Journal of Environmental Studies, 17(1), 28-37.

Ifatemehin, O.O; Ishaya S. and Fanan, U (2010). An Analysis of Temperature Variations Using Remote Sensing Approach In Lokoja Area, Nigeria. Production Agriculture and Technology Journal (PAT), 6(2), 33-44. Available online at http:// www.patnsukjournal.net/currentissue.

Intergovernmental Panel on Climate Change (2014). Climate change 2014: Impacts, adaptation, and vulnerability. Contributions of working group II to the fifth assessment report. Cambridge, England/New York, NY: Cambridge University Press.

Ishaya, S. \& Hassan, S.M. (2013). Analysis of Growing Season Rainfall and Temperature Variability in the Federal Capital Territory of Nigeria. Nigeria Journal of Tropical Geography, 4(2), 471-490.

Ododo, S. (2001). Theatrical Aesthetics and Functional Values of Ekuechi Masquerade Ensemble of the Ebira People in Nigeria. African Study Monographs, 22 (1), 1-36.

Peter, A. \& Ovuyovwiroye, O. (2010). General Overview of Climate Change Impacts in Nigeria. Journal Indonesian of Geography 3(1) 47-55

Stewart, I., \& Oke T.R. (2009). Classifying urban climate field sites by "Local climate zones" The case of Nagano, Japan. Proceedings of the seventh International Conference of Urban Climate, 29th June - $3^{\text {rd }}$ July 2009, Yokohama, Japan.

United Nations (2015). Transforming our world: The 2030 agenda for sustainable development A/RES/70/1. 
United Nations (2019). World Population Prospects 2019:

Highlights. Department of Economic and Social Affairs. 17 June 2019

Yang, X. (2013). Temporal variation of urban surface and air temperature. A published thesis Submitted in Partial Fulfillment of the Requirements for the Degree of Doctor of Philosophy at the Department of Mechanical Engineering, the University of Hong Kong.

Zhao, J. \& Wang, N. (2002). Remote Sensing Analysis of Urbanization Effect on Climate in Lanzhou. Arid Land Geography, 25(1), 90-95. 